Canadian

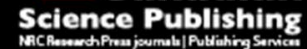

\title{
Canadian Journal of Chemistry
} Revue canadienne de chimie

\section{Synthesis, Structure, and First Reactions of a New Class of Thiacyclophanes}

\begin{tabular}{|r|l|}
\hline Journal: & Canadian Journal of Chemistry \\
\hline Manuscript ID & cjc-2016-0358 \\
\hline Danuscript Type: & Article \\
\hline Complete List of Authors: & $\begin{array}{l}\text { Kannan, Arunachalam; Technische Universität Braunschweig, Chemistry } \\
\text { Hopf, Henning; Technische Universität Braunschweig, Chemistry } \\
\text { Dix, Ina; Novartis Pharma AG, Forum 1, Novartis Campus } \\
\text { Jones, Peter; Technische Universität Braunschweig, Chemistry } \\
\text { Ernst, Ludger; Technische Universität Braunschweig, Chemistry }\end{array}$ \\
\hline Keyword: & $\begin{array}{l}\text { Cyclophanes, cyclophenes, ring contraction, sulfone pyrolysis, Ramberg- } \\
\text { Bäcklund reaction }\end{array}$ \\
\hline \multicolumn{2}{|c}{} \\
\hline
\end{tabular}

SCHOLARONE ${ }^{m}$

Manuscripts 
1 Synthesis, Structure, and First Reactions of a

2

3

4

5

6 Arunachalam Kannan ${ }^{[a]}$, Henning Hopf ${ }^{[a]}$, Ina Dix ${ }^{[a, b]}$, Peter G. 7 Jones $^{[c]}$, and Ludger Ernst ${ }^{[d]}$

8 [a] Institut für Organische Chemie, Technische Universi-

9 tät Braunschweig, Hagenring 30, D-38106 Braunschweig

10 (Germany)

11

12

13

14

15

16

17

18

19

20

21

22

23

24

25

26

\section{New Class of Thiacyclophanes ${ }^{\ddagger}$}

Dedicated to Professor Reginald H. Mitchell

Fax: (+49) 531-391-5388

E-mail: h.hopfetu-bs.de

[b] Current address: Novartis Pharma AG, Forum 1, Novartis Campus, CH-4056 Basel (Switzerland)

E-mail: ina.dix@novartis.com

[c] Institut für Anorganische und Analytische Chemie, Technische Universität Braunschweig, Postfach 3329, D38106 Braunschweig (Germany)

Fax: (+49) 531-391-5387

E-mail: p.jonesetu-bs.de

[d] NMR-Laboratorium der Chemischen Institute, Technische Universität Braunschweig, Hagenring 30, D38106 Braunschweig (Germany)

https://mc06.manuscriptcentral.com/cjc-pubs 
Fax: (+49) 531-391-5245

E-Mail: l.ernstetu-bs.de

[\#] Cyclophanes, Part 75; for Part 74 see ref. ${ }^{1}$

(1)

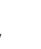

3

\section{4}

Key words: Cyclophanes, cyclophenes, ring contraction, sulfone pyrolysis, Ramberg-Bäcklund reaction, X-ray structural analysis

Abstract: In our effort to prepare [m.n]cyclophanes carrying functional groups in their molecular bridges, the thiacyclophanes 14, 19, 20, and 21 have been prepared by 2 simple routes from the pseudo-gem dibromide $10 \mathbf{a}$ and the 3 corresponding bis-thiol 10b. The triply-bridged bis-thia4 cyclophanes 14, and 19-21 were characterized by their 5 spectroscopic data as well as by X-ray structural analyses. 6 The meta-isomer 20 was oxidized to the bis-sulfone 23, which, 7 on flash vacuum pyrolysis (FVP) yielded a product mixture 8 presumably containing the hydrocarbon 26 with a cleaved 49 molecular bridge. Subjecting 23 to Ramberg-Bäcklund conditions $50\left(\mathrm{CCl}_{4}, \mathrm{NaOH}\right.$, phase transfer catalysis) provided the chloride $\mathbf{2 4}$ 51 in poor yield (9\%), a [2.2]paracyclophane in which the new 52 molecular bridge is fully conjugated. 
Introduction: Compared to the chemical behavior of the

57

70 69 aromatic rings in cyclophanes, much less is known about the reactivity of the bridges that hold these aromatic moieties together. Even when studying the electronic interactions between the latter, most authors are interested in the intraannular, through-space interactions between the aromatic "decks", rather than the through-bond interactions by way of the bridges. Indeed, if one exchanges one of the saturated ethano bridges in [2.2]paracyclohane (1) for an olefinic double bond, as in [2.2] paracyclophene (2) one would not expect any $\Pi-\pi$-interaction (conjugation) at all since, as indicated in formula $\mathbf{2}^{\prime}$ (Scheme 1), the p-orbitals of the olefinic and the adjcacent aromatic units are orthogonal.

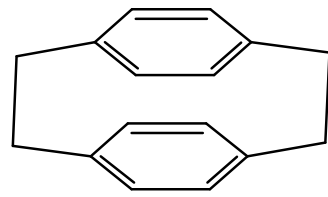

1
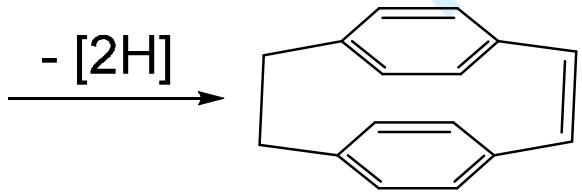

2

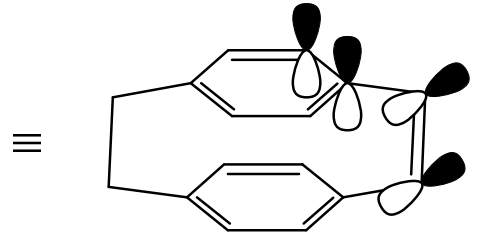

$\mathbf{2}^{\prime}$

Scheme 1 here please

Scheme 1: Electronic interactions between the aromatic rings of [2.2] paracyclophanes.

Increasing the length of the (unsaturated) bridge(s) should result in a greater flexibility of this structural element and hence, by allowing more non-orthogonal orientations of the 
79 respective p-orbitals, lead to more conjugation between the 80 aromatic rings.

81 We have recently described the first [2.2]paracyclophane 82 derivatives possessing such lengthened unsaturated bridges: ${ }^{2}$

83 The pseudo-geminally substituted dienyne $\mathbf{3}$ and the enediyne 4, 84 as well as its pseudo-ortho isomer 5 (Scheme 2), were prepared 85 and some of their chemical properties studied.

86

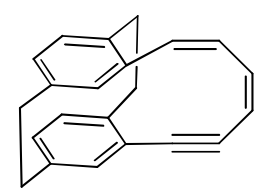

3

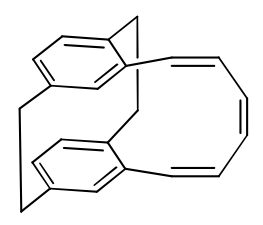

6

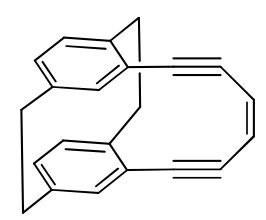

4

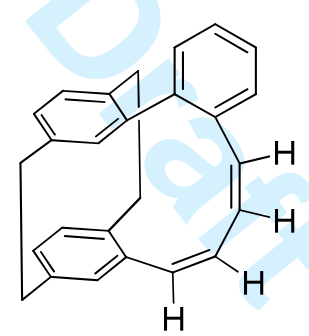

7

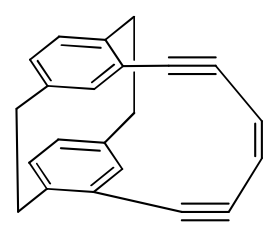

5
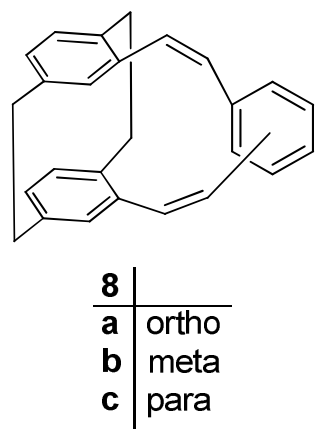

87

88

89

90

91

92

93

94 95 also assumed to be characteristic for the yet unknown $\mathbf{6}$, we

Scheme 2: A selection of [2.2]paracyclophane derivatives with a lengthened unsaturated bridge.

94 Since the hydrocarbons 3-5 are not very stable, ${ }^{2}$ a property 6 decided to replace at least one of the double bonds by a 
97 benzene ring. This could be achieved in two ways: Exchange of

98 a terminal double bond of the bridge by a benzene ring results 99 in the generation of benz-annelated hydrocarbon 7, whereas the 100 analogous substitution of the central double bond of 6 by a

101 benzene ring produces $\mathbf{8 a}$ (Scheme 2). Note that the double 102 bonds in 7 and 8 cannot only be anchored in the ortho-position 103 as in $\mathbf{8 a}$, but also in the meta- and para-orientation: $\mathbf{8 b}$ and 104 8c, respectively.

105 For the preparation of hydrocarbons of type 8 we decided to 106 proceed as illustrated by the retrosynthetic Scheme 3 for the 107 model system 8c:

108

109

110

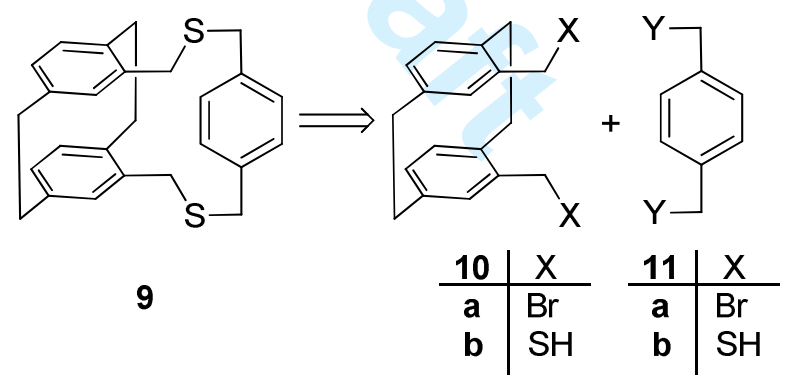

111

112 Scheme 3 here please

113

114 Scheme 3: Preparation of the hydrocarbons 8: retrosynthetic analysis.

116

117

118 One of the most often employed strategies to prepare bridged 119 aromatic systems involves the preparation of sulfides, which https://mc06.manuscriptcentral.com/cjc-pubs 
120 are subsequently subjected to ring contraction. This could

121 start from the sulfide and use the S-analogous Stevens122 rearrangement ${ }^{3}$ or oxidize the sulfide first to a sulfone and 123 then remove the $\mathrm{SO}_{2}$-linker thermally ("sulfone pyrolysis") ${ }^{4}$.

124 Access to 9 could be provided by either coupling the pseudo125 gem-dibromide $10 \mathrm{a}$ or the pseudo-gem bis-thiol 10b with the 126 para-xylylene dibromides $11 \mathbf{a}$ or bis-thiols $11 \mathbf{b}$. To prepare 127 various isomers of 9 and products derived therefrom, the 128 appropriate isomers of 10 and 11 have to be used. For the time 129 being we wish to keep the functional groups in the

130 [2.2] paracyclophane derivative 10 in the pseudo-gem position, 131 since this guarantees closest proximity of the bridging 132 elements in this part of the molecules.

133 In our first coupling experiment (Scheme 4) we reacted the 134 pseudo-gem dibromide 10a with either the ortho- (12) or the 135 meta-xylylenedithiol 13 in the presence of potassium hydroxide 136 in benzene/ethanol under high dilution conditions (Scheme 4). 137 
139

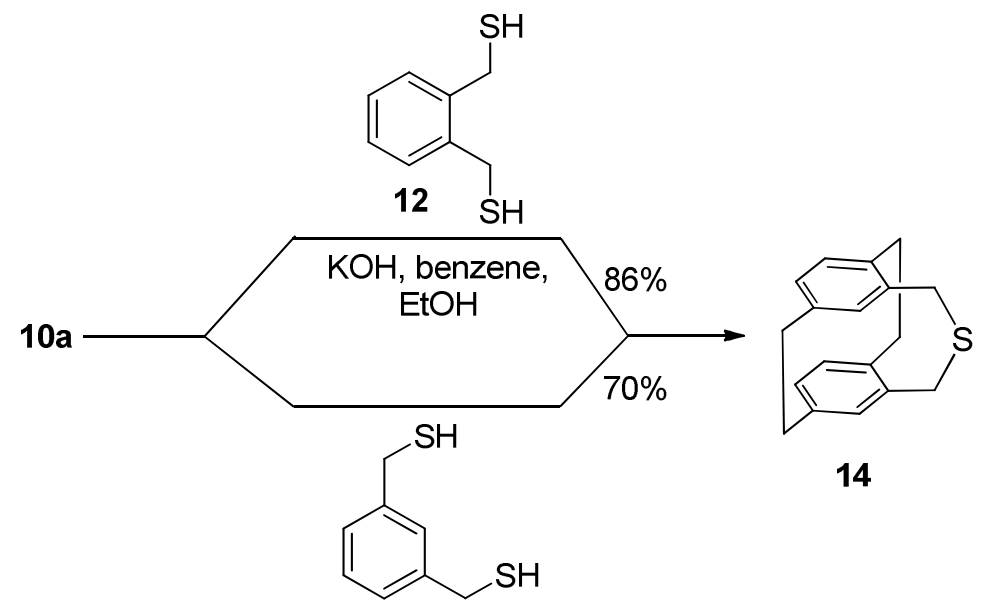

13

140

141

Scheme 4 here please

142

143 Scheme 4: Coupling of the pseudo-gem cyclophane 10a with

144 ortho-, 12, and meta-xylylenedithiol, 13.

145

146 To our surprise in neither case could the desired bis-sulfides

147 be obtained. Instead in both experiments the triply bridged

148 [3.2.2] thiacyclophane $\mathbf{1 4}$ was obtained in approximately the

149 same yield.

150 The compound was characterized by its spectroscopic data (see

151 Experimental section) and an X-ray structural study.

152 The molecular structure of 14 in the crystal is shown in Fig.

1531.

154

155

Fig. 1 here please

156

157

https://mc06.manuscriptcentral.com/cjc-pubs 
158

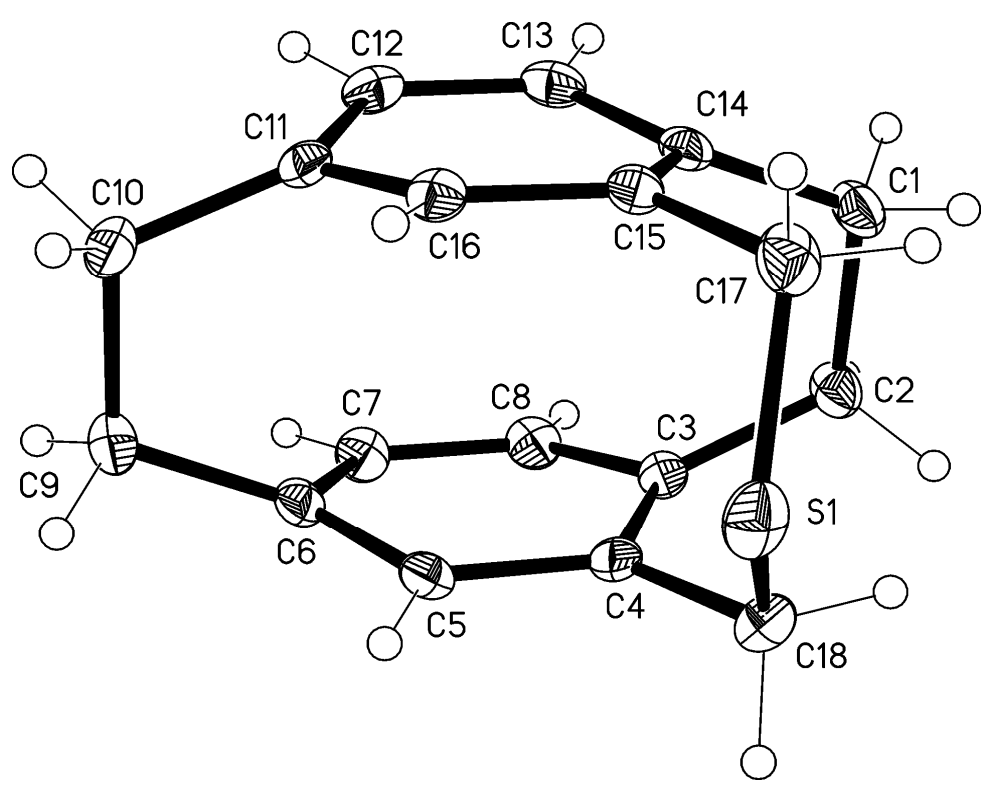

159

160 Fig. 1. The molecular structure of compound 14 in the crystal.

161 Ellipsoids represent 50\% probability levels. Selected

162 molecular dimensions ( $\AA$ and $\left.{ }^{\circ}\right)$ : C1-C2 1.576(3), C9-C10

163 1.591(3), C17-S1 1.813(3), C18-S1 1.815(3); C2-C1-C14

164 112.2(2), C1-C2-C3 113.0(2), C6-C9-C10 113.1(2), C9-C10-C11

165 112.8(2), S1-C17-C15 114.7(2), S1-C18-C4 116.0(2), C17-S1-C18

$166102.05(12) ; C 15-C 17-S 1-C 858.7(2), C 4-C 18-S 1-C 17-61.9(2)$.

167

168 The molecule of 14 (Fig. 1) displays approximate mirror

169 symmetry (r.m.s. deviation $0.29 \AA$ ). The introduction of the 170 extra bridge scarcely alters the distortions that are well-

171 known for [2.2] paracyclophane ${ }^{1,5}$, features of which include

172 lengthened bridge bonds, widened bridge angles, narrow ring 173 angles at the bridgehead atoms; see the figure caption and the 174 Experimental section for individual values. The flattened boat 175 form adopted by the rings, in which the bridgehead atoms lie 
176 some 0.13-0.16 $\AA$ out of the plane of the other four ring

177 atoms, is also retained, and the interplanar angle between the 178 rings (excluding bridgehead atoms) is $2.9^{\circ}$. The bond angles in

179 the $\mathrm{CH}_{2}-\mathrm{S}-\mathrm{CH}_{2}$ bridge may be compared to values obtained from a 180 search of the Cambridge Database ${ }^{6}$ for the moiety $\mathrm{C}-\mathrm{CH}_{2}-\mathrm{S}-\mathrm{CH}_{2}-\mathrm{C}$

181 with two-coordinate central sulfur: $113.4^{\circ}$ for the angle at

182 the methylene carbon and $101.4^{\circ}$ for the angle at sulfur,

183 averaged from 1758 individual values.

184

185 A reasonable mechanism for the formation of $\mathbf{1 4}$ is summarized 186 in Scheme 5.

187

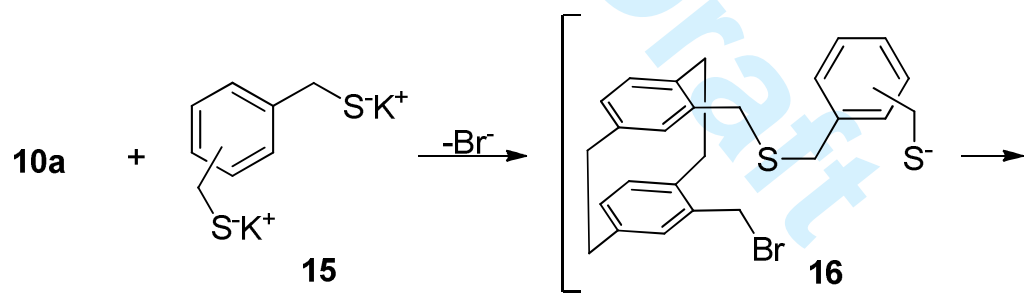

188

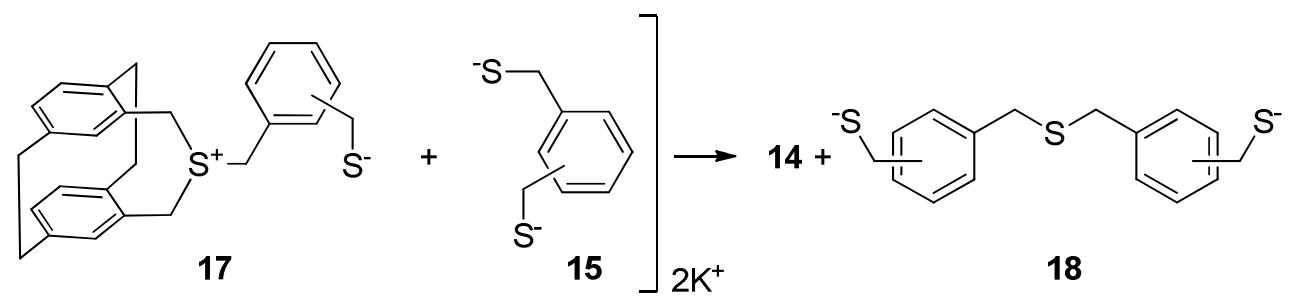

189

190

191

Scheme 5 here please

192 
193 Scheme 5: Mechanism of formation of the triply-bridged

194 cyclophane 14 from 10a and the dipotassium salts of various 195 xylylenedithiols, 15.

196

197 We propose that in the first step the salt 15 attacks the

198 dibromide $10 \mathrm{a}$ in an $\mathrm{S}_{\mathrm{N}} 2$-substitution and yields the monobromide

199 16. This, in principle, could react similarly for a second 200 time, but in an intramolecular fashion, to yield the desired 201 disulfides, e.g. 9. In fact, the required ring-closure takes 202 place, but with the sterically much closer sulfur atom of the 203 thioether function as shown in 16. This results in the 204 generation of the sulfonium ion 17, which in the final step is 205 cleaved by the potassium salt 15 to provide the isolated 206 thioether 14. The tris-sulfur compound 18, which is also 207 produced, could participate in the process again to finally 208 yield the polymeric material which is also observed. We had 209 previously noted that the yields of this type of coupling 210 reactions to prepare thiacyclophanes are influenced by the 211 binding of the respective functional groups: thus, taking a 212 thiol of one coupling partner and reacting it with the bromide 213 of the other can yield different results than the combination 214 in which these two functional groups are reversed. ${ }^{7}$

215 We hence decided to replace the pseudo-geminal dibromide 10a 216 by the dithiol 10b. This derivative was prepared by reacting 217 10a with thiourea and hydrolysis of the resulting bis-iso- 
<smiles></smiles>

10a $\frac{\text { 1. }\left(\mathrm{H}_{2} \mathrm{~N}\right)_{2} \mathrm{C}=\mathrm{S} \text {, THF }}{\text { 2. EDA, } \mathrm{H}_{2} \mathrm{O} \text {, dioxane }}$

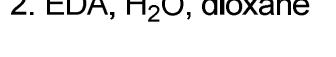

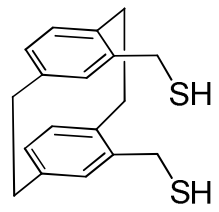

10b $(70 \%)$

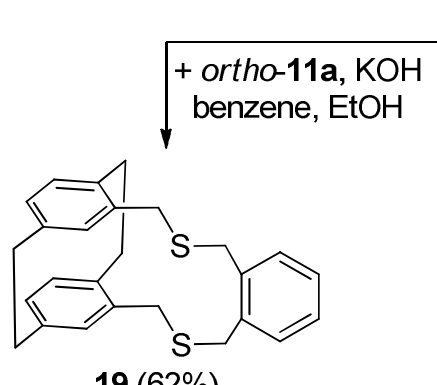

$19(62 \%)$

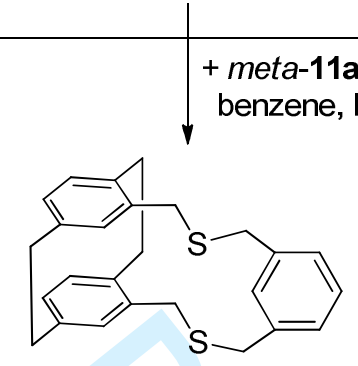

$20(80 \%)$

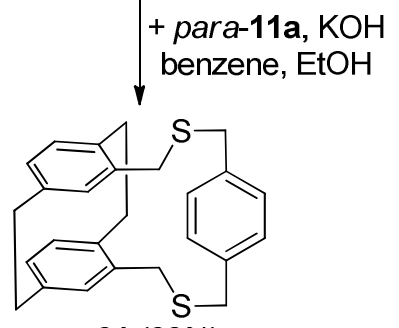

$21(32 \%)$

228 from 10b.

229

230

When $\mathbf{1 0 b}$ was reacted with the ortho-, meta- and para-isomer of

9a, the anticipated bisthioethers 19-21 were all formed. In the first two cases the yields were good, in the third case 233 rather low. We would assume that this isomer is the most 234 strained and that the transition state for the final 235 intramolecular coupling process is the least favorable. 
236 All compounds were characterized by their spectroscopic and 237 analytical data (see Experimental section), and also by X-ray 238 structural analyses.

239 The molecular structure of 19 in the crystal is shown in Fig. 2402.

241

242 Fig. 2 here please

243

244

245

246

24 24 249

250

251

252

253 $25454.4(3), \quad C 15-C 26-S 2-C 25-146.3(2), \quad C 26-S 2-C 25-C 20-34.9(3)$,

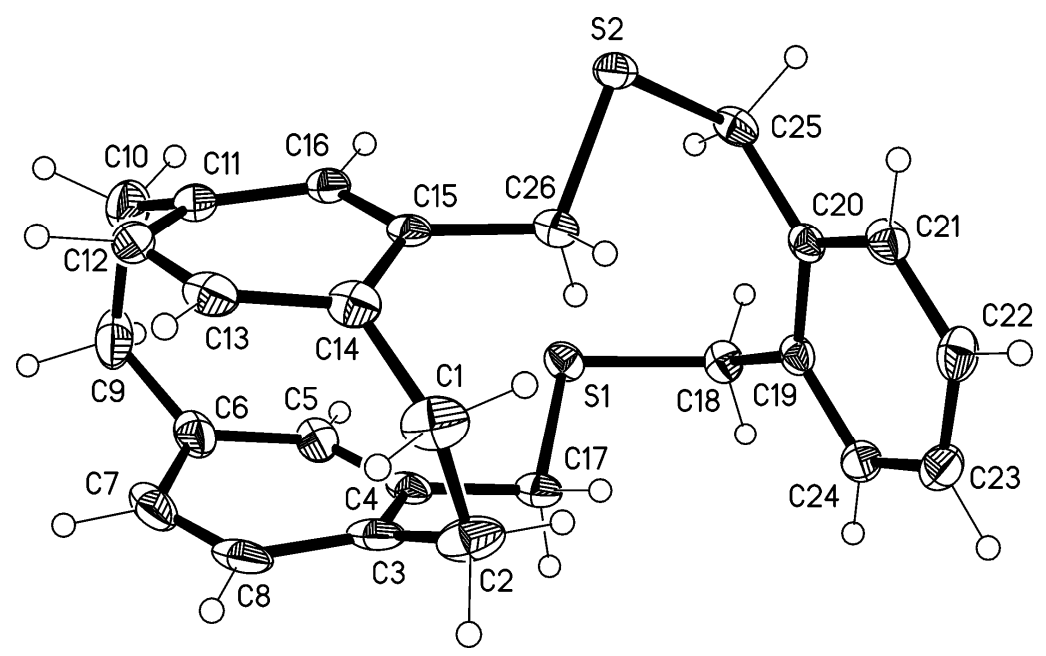

45 Fig. 2. The molecular structure of compound 19 in the crystal.

246 Ellipsoids represent 30\% probability levels. Selected

247 molecular dimensions ( $\AA$ and $\left.{ }^{\circ}\right):$ C1-C2 1.589(5), C9-C10 248 1.572(5), C17-S1 1.824(3), C18-S1 1.823(3), C25-S2 1.832(3), $249 \mathrm{C} 26-\mathrm{S} 21.819(3) ; \mathrm{C} 2-\mathrm{C} 1-\mathrm{C} 14112.1(3), \mathrm{C} 1-\mathrm{C} 2-\mathrm{C} 3112.4(3), \mathrm{C} 6-\mathrm{C} 9-$ $250 \mathrm{C} 10111.9(3), \mathrm{C} 9-\mathrm{C} 10-\mathrm{C} 11114.0(3), \mathrm{S} 1-\mathrm{C} 17-\mathrm{C} 4111.4(2), \mathrm{S} 1-\mathrm{C} 18-$ $251 \mathrm{C} 19114.7(2), \mathrm{S} 2-\mathrm{C} 26-\mathrm{C} 15$ 113.8(2), S2-C25-C20 113.7(2), C17-

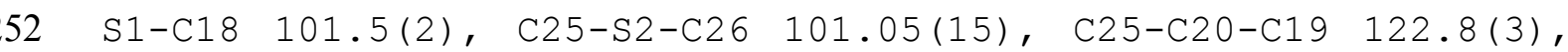
$253 \mathrm{C} 18-\mathrm{C} 19-\mathrm{C} 20122.7(3) ; \mathrm{C} 4-\mathrm{C} 17-\mathrm{S} 1-\mathrm{C} 18$ 163.0(2), C17-S1-C18-C19255 C5-C4-C17-S1 33.9(4), C16-C15-C26-S2 50.8(4). 
257 In the ortho-isomer 19 (Fig. 2), the [2.2]paracyclophane 258 framework retains its usual features (see above), although the 259 interplanar angle is slightly increased to $4.2^{\circ}$. The aromatic 260 ring c19-24 of the newly introduced bridge is to a good 261 approximation perpendicular to the two rings of the 262 paracyclophane unit (this is also the case for the other two 263 isomers, see below), and shows little sign of strain except 264 for the slightly widened angles C25-C20-C19 and C18-C19-C20 to 265 the sulfur-containing bridges. The conformation of these 266 bridges is completely different; the atom $\mathrm{S} 1$ is directed into 267 the space between the cyclophane rings [torsion angle c5-C4268 C17-S1 33.9(4) $]$, whereas S2 points away from the cyclophane $269\left[\mathrm{C} 16-\mathrm{C} 15-\mathrm{C} 26-\mathrm{S} 250.8(4)^{\circ}\right]$.

270 The molecular structure of 20 in the crystal is displayed in 271 Fig. 3.

272

Fig. 3 here please

273

274 
275

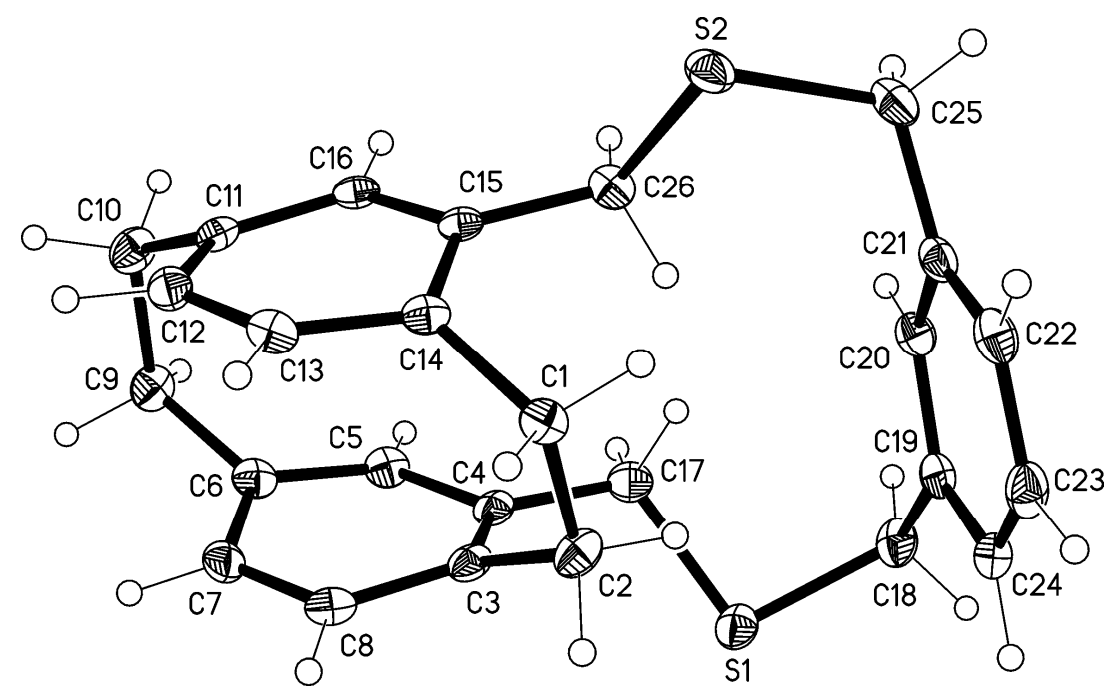

276

277

278 Fig. 3. The molecular structure of compound 20 in the crystal.

279 Ellipsoids represent 30\% probability levels. Selected

280 molecular dimensions ( ${ }^{\circ}$ and $\left.{ }^{\circ}\right)$ : C1-C2 1.585(4), C9-C10

281 1.585(4), C17-S1 1.820(3), C18-S1 1.826(3), C25-S2 1.835(3),

282 C26-S2 1.821(3); C2-C1-C14 113.4(2), C1-C2-C3 113.9(2), C6-C9-

283 C10 113.3(2), C9-C10-C11 113.3(2), S1-C17-C4 114.2(2), S1-C18284 C19 112.4(2), S2-C26-C15 113.7(2), S2-C25-C21 113.0(2), C17$285 \mathrm{~S} 1-\mathrm{C} 1898.75(15), \mathrm{C} 25-\mathrm{S} 2-\mathrm{C} 2698.27(15) ; \quad \mathrm{C} 4-\mathrm{C} 17-\mathrm{S} 1-\mathrm{C} 18$ 286 153.0(2), C17-S1-C18-C19 67.2(3), C15-C26-S2-C25 163.9(2), $287 \mathrm{C} 26-\mathrm{S} 2-\mathrm{C} 25-\mathrm{C} 21-58.7(3), \quad \mathrm{C} 3-\mathrm{C} 4-\mathrm{C} 17-\mathrm{S} 158.1(3), \quad \mathrm{C} 14-\mathrm{C} 15-\mathrm{C} 26-\mathrm{S} 2$ $288-64.2(3)$

289

290 The molecule of the meta-isomer 20 (Fig. 3) is much more 291 regular than that of 19 and displays approximate mirror 292 symmetry (r.m.s. deviation $0.15 \AA$ ). Both sulfur atoms point 293 away from the cyclophane core, which again retains its 
customary structural features (see above), although the

295 interplanar angles between the cyclophane decks is $5.5^{\circ}$. The

296 additional aromatic ring c19-24 is not itself distorted, but

297 incipient strain may be indicated by the fact that the

298 substituent atoms C18 and C25 are displaced by 0.16 and $0.14 \AA$

299 respectively out of the ring plane towards the cyclophane.

300 The molecular structure of the para-isomer $\mathbf{2 1}$ in the crystal

301 is shown in Fig. 4.

302

303

Fig. 4 here please

304

305

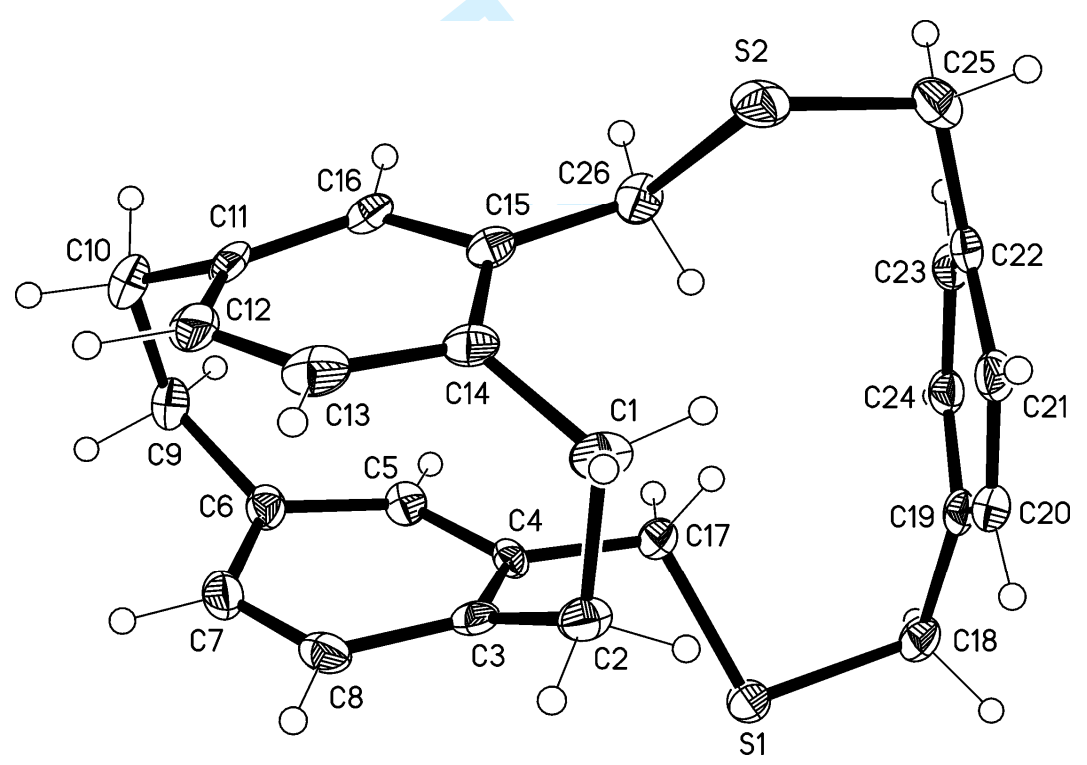

306

307 Fig. 4. The molecular structure of compound 21 in the crystal

308 (one of two independent molecules; solvent omitted).

309 Ellipsoids represent 30\% probability levels. Selected

310 molecular dimensions ( $\AA$ and $\left.{ }^{\circ}\right)$ for this molecule: C1-C2

311 1.587(4), C9-C10 1.574(5), C17-S1 1.837(3), C18-S1 1.850(3), 
312 C25-S2 1.829(4), C26-S2 1.831(3); C2-C1-C14 114.1(3), C1-C2-C3

313 113.9(2), C6-C9-C10 113.3(2), C9-C10-C11 113.3(2), S1-C17-C4

314 114.2(3), S1-C18-C19 110.9(2), S2-C26-C15 112.1(2), S2-C25-C22

$315111.7(2), \mathrm{C} 17-\mathrm{S} 1-\mathrm{C} 18100.52(15), \mathrm{C} 25-\mathrm{S} 2-\mathrm{C} 26100.7(2) ; \mathrm{C} 4-\mathrm{C} 17-$

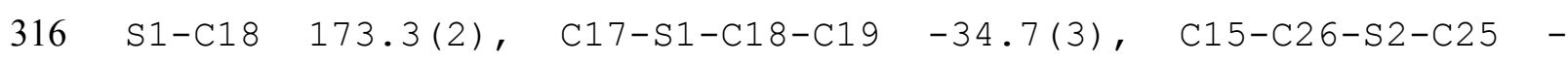

$317166.8(2), \mathrm{C} 26-\mathrm{S} 2-\mathrm{C} 25-\mathrm{C} 2248.5(3), \mathrm{C} 3-\mathrm{C} 4-\mathrm{C} 17-\mathrm{S} 1-63.8(4), \mathrm{C} 14-$

318 C15-C26-S2 55.2(4).

319

320 The para-isomer 21 (Fig. 4) crystallizes with two independent

321 but similar molecules in the asymmetric unit, together with a

322 cyclohexane molecule that is disordered across an inversion

323 centre. Both molecules display approximate mirror symmetry,

324 with r.m.s. deviations 0.14 and $0.10 \AA$ respectively; the fit

325 of one molecule to the other gives an r.m.s. deviation of 0.11

$326 \AA$. There are indications that this isomer is the most strained

327 of the three; the paracyclophane decks are tilted by $7.5^{\circ}$, and

328 the substituent atoms C18 and C25 are displaced by 0.39 and

$3290.35 \AA$ respectively out of the plane of the ring C19-24

330 towards the cyclophane core.

331

332 In another coupling experiment we tried to combine the two

333 pseudo-gem-[2.2] paracyclophanes $10 \mathrm{a}$ and $10 \mathrm{~b}$ with each other.

334 In the first experiment with potassium hydroxide as the base, 335 only the thiaphane 14 was obtained in good yield (Scheme 7) 


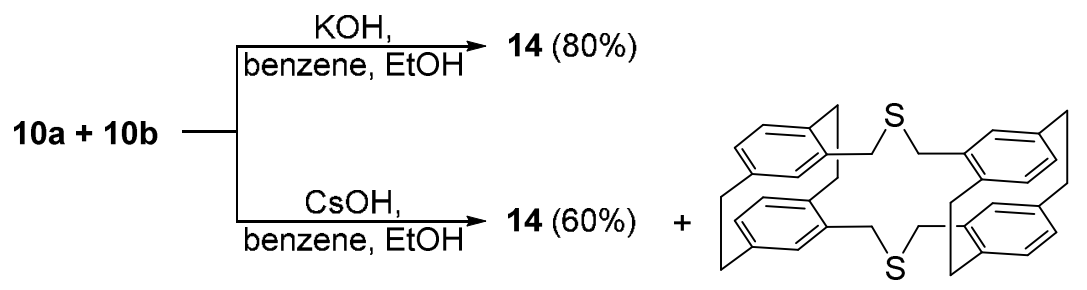

$22(5 \%)$

338

339

340

341

342

343

344 This was still the main product when we changed to cesium

345 hydroxide as the base; but in this case we also isolated a small amount of a disulfide to which we assign the "dimeric" structure $\mathbf{2 2}$ according to its spectroscopic and analytical

352 however, that besides the functionality of the respective

353 building blocks, the base employed in their coupling can also 354 play a significant role.

355

356 Summarizing our work up to this point, we have been successful 357 in synthesizing and characterizing new thiacyclophane systems, 358 the disulfides 19-21, by simple and effective routes, 359 compounds which are now ready for further transformation. 
360 To obtain a first impression concerning their reactivities, we 361 studied the ring contraction of 20 , hoping to obtain a 362 representative of the hydrocarbons 8 shown in scheme 2 (the 363 meta-isomer, 8b).

364 Towards this end the meta-derivative 20 was first oxidized to 365 the bis-sulfone 23 in excellent yield with meta366 chloroperbenzoic acid (MCPBA) in dichloromethane in the 367 presence of acetic acid (Scheme 8).

368

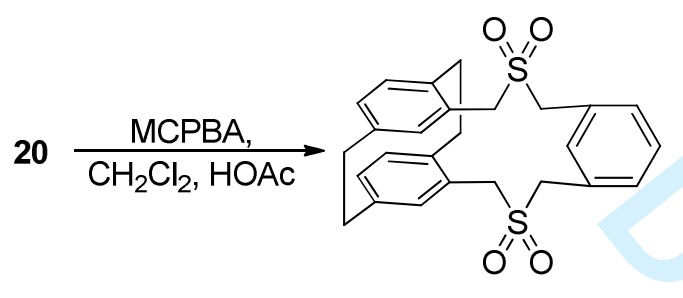

$23(90 \%)$

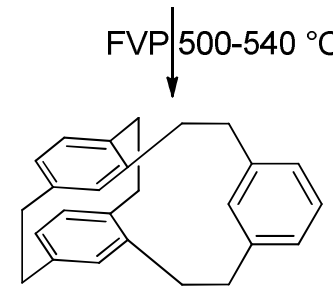

25

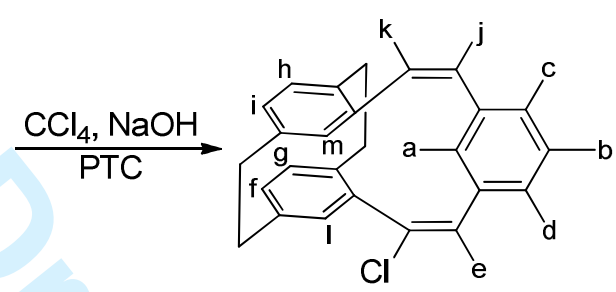

$24(9 \%)$

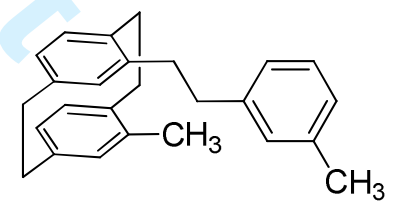

26 (+ unidentified material)

370

371

Scheme 8 here please

372 Scheme 8: First reactions with the meta-bis-sulfide 20: ring373 contractions. Letters a-m in formula $\mathbf{2 4}$ indicate protons 374 assigned by NMR (see Experimental).

375

376 Neither the conventional Ramberg-Bäcklund reaction ${ }^{8}$ nor 377 employing the modified version of Chan et al. ${ }^{9}$, mixing powdered $378 \mathrm{KOH}$ and aluminum oxide, lead to isolable products. 
379 Therefore, the reaction was carried out under phase-transfer

380 conditions, using carbon tetrachloride as the halogenating

381 reagent in the first step (Scheme 8). In this case, a diene

382 was produced indeed, although in low yield (9\%). According to

383 its spectral data (see Experimental section) it bore a

384 chlorine substituent at one of its double bonds. There are

385 reports in the literature ${ }^{10}$ that under these conditions

386 polyhalhalogenation takes place in the first step of the

387 Ramberg-Bäcklund process causing the formation of vinylhalides

388 after the sulfur dioxide has been extruded.

389 The structure of $\mathbf{2 4}$ was derived from close inspection of the

390 coupling patterns in its ${ }^{1} \mathrm{H}$ NMR spectrum and from useful long-

391 range correlations in its $\mathrm{H}, \mathrm{H}-\mathrm{COSY}$ spectrum. The deshielded

392 protons, $\mathrm{H}^{\mathrm{a}}-\mathrm{H}^{\mathrm{d}}$ in formula 24, of the m-disubstituted benzene

393 ring were easily identified. Protons $H^{j}$ and $H^{k}$ with a mutual

394 coupling of $11.0 \mathrm{~Hz}$ indicate a cis-C=C double bond. Olefinic

395 proton $\mathrm{H}^{j}$ displayed long-range correlations with $\mathrm{H}^{\mathrm{a}}$ and $\mathrm{H}^{\mathrm{C}}$, so

396 these latter ones are situated ortho to $\mathrm{H}^{j}$ of the $-\mathrm{CH}^{\mathrm{k}}=\mathrm{CH}^{j}-$

397 bond. The slightly broadened singlet of olefinic proton $\mathrm{H}^{\mathrm{e}}$ had

398 long-range cross-peaks with $\mathrm{H}^{\mathrm{a}}$ and $\mathrm{H}^{\mathrm{d}}$, thus determining the

399 position of the second olefinic bridge, $-\mathrm{C}(\mathrm{Cl})=\mathrm{CH}^{\mathrm{e}}-$. Proton $\mathrm{H}^{\mathrm{k}}$

400 of the first bridge correlates with the isolated proton, $\mathrm{H}^{\mathrm{m}}$, of

401 the "upper" [2.2]paracyclophane deck, while the isolated

402 proton, $\mathrm{H}^{1}$, of the "lower" deck shows no correlation with any

403 olefinic proton because its ortho-benzylic position is 
404 occupied by the chloro substituent, the presence of which is 405 evident from the mass spectrum and the elemental analysis.

406

407 To prepare the parent system, from which $\mathbf{2 4}$ is formally 408 derived, the hydrocarbon 25, we subjected the bissulfone 23 to 409 flash vacuum pyrolysis (FVP) at 500-540 ${ }^{\circ} \mathrm{C}$. From the 410 pyrolysate, a hydrocarbon mixture could be isolated by column 411 chromatography in ca. 22\% yield. Acoording to its NMR 412 spectroscopic data, this must contain components carrying 413 methyl groups as in 26 (Scheme 8 and Experimental section). A 414 rationalization for these signals would involve cleavage of 415 one ethano bridge of the presumed intermediate 25. Similar 416 cleavage products have been obtained by pyrolysis of 417 paracyclophane hydrocarbons, including the parent system 1. 418 Their formation presumably takes place via diradicals formed 419 by homolysis of an ethano bridge. ${ }^{11}$

420 We hence assume that 25 is generated as a reaction 421 intermediate, that does not survive the harsh pyrolysis 422 conditions in this case.

423 Conclusions: We have shown that dithiacyclophanes can be 424 prepared readily by well-established routes in high yield. 425 Exploratory experiments demonstrate that these intermediates 426 can be converted into novel cyclophanes containing unsaturated 427 bridges, compounds which are of interest in the study of 428 conjugation effects between the rings ("decks") of layered 429 organic compounds. 


\section{References:}

432 (1) Lehne, V.; Ernst, L.; Hopf, H. Synlett 2016, in press.

(2) Dix, I.; Bondarenko, L.; Jones, P. G.; Ernst, L.; Ibrom, 434 K.; Grunenberg, J.;, Boese, R.; Hopf, H. Chem. Eur. J. 2014, $43520,16360-16376$.

436 (3) For a typical example see Mitchell, R. H.; Boekelheide, V. 437 Tetrahedron Lett. 1970, 1197-1201.

438 (4) Vögtle, F.; Rossa L. Angew. Chem. 1979, 91, 534-549; 439 Angew. Chem. Int. Ed. Engl. 1979, 18, 515-529.

440 (5) Keehn P. M. in Keehn, P. M.; Rosenfeld, S. M. (eds.), 441 Cyclophanes, Academic Press, New York, 1983, Vol. 1, Chapter $4423, \mathrm{pp} 69-238$.

443 (6) Groome, C. R.; Allen, F. H. Angew. Chem. 2014, 126, 675444 684; Angew. Chem. Int. Ed. 2014, 53, 662-671.

445 (7) Bodwell, G.; Ernst, L.; Hopf,H.; Jones, P. G.; McNally, J. 446 P.; Schomburg, D. Chem. Ber. 1990, 123, 2381-2386.

447 (8) Review: Paquette, L. A. Org. Reactions, 1977, 25, 1-71.

448 (9) Chan. T. L.; Fong, S.; Li, Y.; Man, T.-O.; Poon, C.-D. J. 449 Chem. Soc. Chem. Commun. 1994, 1771-1772.

450 (10) Yang, F. M.; Lin, S. H. J. Org. Chem. 1997, 62, 27274512731.

452 (11) Reich, H. J.; Cram, D. J. J. Am. Chem. Soc. 1967, 89, $453 \quad 3078-3080$.

454 (12) Trampe, S.; Menke, K.; Hopf, H. Chem. Ber. 1977, 110, $455 \quad 371-372$. 
464

465

466

467

468

469

470

471

472

473

474

475

476

477

478

479

$$
\text { 然 }
$$


ethanol and/or acetonitrile, Beckman UV 5230. - MS: EI (70

$481 \mathrm{eV})$, Finnigan MAT 8436.

482 The dibromide 10 a was prepared according to the method 483 described in the literature: ${ }^{12}$

484

485 General procedure for assembling thiacyclophanes: A solution 486 containing equimolar amounts (1 mmol each) of the appropriate 487 dibromide and the dithiol in degassed benzene $(100 \mathrm{~mL})$ was 488 added by a syringe pump to a well-stirred solution of 489 potassium hydroxide $(0.14 \mathrm{~g}, 2.5 \mathrm{mmol}$ ) in ethanol (95\%, 800 $490 \mathrm{~mL}$ ) during 8-10 h. After the addition was complete, the 491 mixture was stirred for an additional $8 \mathrm{~h}$ period. The solvent 492 was removed in vacuo and the crude product as chromatographed 493 on silica gel to give the corresponding cyclophane.

494

495 4,15-Bis (mercaptomethyl[2.2]paracyclophane (10b): A solution 496 of 4,15-bis (bromomethyl) [2.2] paracyclophane (10a, 2.44 9, 6.2 $497 \mathrm{mmol})$ and thiourea $(0.95 \mathrm{~g}, 12.4 \mathrm{mmol})$ in anhydrous THF (60 $498 \mathrm{~mL}$ ) was heated to reflux for $12 \mathrm{~h}$. The mixture was cooled to 499 room temp. and the precipitated isothiouronium salt was 500 removed by filtration and dried. The salt was dissolved in 501 water/dioxane $(1: 2, \mathrm{~V} / \mathrm{v}, 180 \mathrm{~mL})$ under nitrogen and to this 502 solution was added ethylene diamine (0.57 g, 9.4 mmol). The 503 mixture was heated to reflux under nitrogen for $12 \mathrm{~h}$, cooled 504 to room temp., and hydrochloric acid (2 N) was added for 505 hydrolysis until a $\mathrm{pH}$ of 4 was reached. The solvent was 
506 removed in vacuo, and the crude product was chromatographed 507 using dichloromethane/hexane $(1: 1, \mathrm{~V} / \mathrm{V})$ as the eluent: $1.30 \mathrm{~g}$ $508(70 \%)$ of $10 \mathrm{~b}$ as a colorless powder, $\mathrm{m} . \mathrm{p} .85{ }^{\circ} \mathrm{C} . \quad-{ }^{1} \mathrm{H}$ NMR: $\delta=$ $5091.46(t, J=7.0 \mathrm{~Hz}, 2 \mathrm{H}), 2.95-3.08(\mathrm{~m}, 6 \mathrm{H}), 3.38$ (m, $\left.510 \mathrm{AA}^{\prime} \mathrm{XX}^{\prime}, N=9.9 \mathrm{~Hz}, 2 \mathrm{H}\right), 3.45(\mathrm{dd}, J=12.8,6.9 \mathrm{~Hz}, 2 \mathrm{H})$, $5113.85(\mathrm{dd}, J=12.8,6.9 \mathrm{~Hz}, 2 \mathrm{H}), 6.32(\mathrm{~d}, J=1.7 \mathrm{~Hz}, 2 \mathrm{H})$, $5126.45(\mathrm{dd}, J=7.7,1.7 \mathrm{~Hz}, 2 \mathrm{H}), 6.48 \mathrm{ppm}(\mathrm{d}, J=7.7 \mathrm{~Hz}, 2 \mathrm{H})$. $513-{ }^{13} \mathrm{C}$ NMR: $\delta=27.4$ (t), 31.7 (t), 34.9 (t), 132.4 (d), 132.5 $514(\mathrm{~d}), 135.3(\mathrm{~d}), 136.0(\mathrm{~s}), 140.01(\mathrm{~s}), 140.02(\mathrm{~s}) .-\mathrm{MS}: \mathrm{m} / \mathrm{z}$ $515\left(\frac{\circ}{0}\right)=300\left(18, \mathrm{M}^{+}\right), 267(40), 266(86), 147(100) . \quad$ HRMS: $516 \mathrm{C}_{18} \mathrm{H}_{20} \mathrm{~S}_{2}$ : calcd.: 300.100 ; found: 300.100 .

517

518 Attempted coupling of 10a with o-xylylene dithiol (12):

519 According to the above general procedure it was attempted to 520 couple the dibromide $10 \mathrm{a}(0.40 \mathrm{~g}, 1.0 \mathrm{mmol})$ with o-xylylene 521 dithiol (12, 0.17 g, $1.0 \mathrm{mmol})$. Purification of the obtained 522 crude reaction product by silica gel chromatography with 523 dichlormethane/hexae (3:7, v/v) afforded the thiacyclophane 14 524 as colorless needles $(0.21 \mathrm{~g}, 80 \%), \mathrm{m} . \mathrm{p} .240^{\circ} \mathrm{C}$. The compound 525 has been described previously, ${ }^{13}$ but its spectroscopic data are 526 incomplete in the literature. $-{ }^{1} \mathrm{H}$ NMR: $\delta=2.84-3.07$ (m, $\left.6 \mathrm{H}\right)$, $5273.29-3.41(\mathrm{~m}, 4 \mathrm{H}), 4.09(\mathrm{~d}, J=14.7 \mathrm{~Hz}, 2 \mathrm{H}), 6.24(\mathrm{dd}, J=$ $5287.9,1.9 \mathrm{~Hz}, 2 \mathrm{H}), 6.34(\mathrm{~d}, J=7.9 \mathrm{~Hz}, 2 \mathrm{H}), 6.85 \mathrm{ppm}(\mathrm{d}, J=$ $5291.9 \mathrm{~Hz}, 2 \mathrm{H}) . \quad-{ }^{13} \mathrm{C}$ NMR: $\delta=32.3$ (t), 32.5 (t), 35.3 (t), $530131.7(d), 134.2(d), 134.6(d), 135.0(s), 138.3(s), 140.3$ 531 ( s ) ppm. 
533 Attempted coupling of 10a with m-xylylene dithiol (13): As

534 above 10a $(0.40 \mathrm{~g}, 1.0 \mathrm{mmol})$ was attempted to be coupled with

535 m-xylylene dithiol $(0.17 \mathrm{~g}, 1 \mathrm{mmol})$. Again, only the

536 intramolecularly generated 14 was obtained $(0.19$ 9, 70\%).

537

538 Dithiacyclophane 19: According to the above general procedure 539 was coupled 10b (0.60 g, 2 mmol) with o-xylylene dibromide (o-

$54011,0.53 \mathrm{~g}, 2 \mathrm{mmol})$. The crude product was purified by silica

541 gel column chromatography with dichloromethane/hexane (3:7, $542 \mathrm{~V} / \mathrm{v})$ to provide 19 as colorless needles $(0.50 \mathrm{~g}, 62 \%)$, m. p. $543211{ }^{\circ} \mathrm{C} . \quad-{ }^{1} \mathrm{H} \quad \mathrm{NMR}: \delta=2.74-3.07(\mathrm{~m}, 8 \mathrm{H}), 3.48,3.53(\mathrm{AB}$ 544 system, $J=15.1 \mathrm{~Hz}, 4 \mathrm{H}), 3.78(\mathrm{~d}, J=13.9 \mathrm{~Hz}, 2 \mathrm{H}), 4.33$ $545(\mathrm{~d}, J=13.9 \mathrm{~Hz}, 2 \mathrm{H}), 6.37(\mathrm{~d}, J=7.7 \mathrm{~Hz}, 2 \mathrm{H}), 6.42(\mathrm{dd}, \mathrm{J}$ $546=7.7,1.8 \mathrm{~Hz}, 2 \mathrm{H}), 6.63(\mathrm{~d}, \mathrm{~J}=1.8 \mathrm{~Hz}, 2 \mathrm{H}), 7.35,7.55$ $547\left(\mathrm{AA}^{\prime} \mathrm{XX} \mathrm{X}^{\prime}, \quad N=9.2 \mathrm{~Hz}, 4 \mathrm{H}\right) \cdot-{ }^{13} \mathrm{C} \mathrm{NMR}: \delta=31.3$ (t), 31.7 (t), $54833.2(t), 35.0(t), 127.6(d), 131.11(d), 131.17$ (d), 131.25 $549(\mathrm{~d}), 133.9(\mathrm{~d}), 136.3(\mathrm{~s}), 136.6(\mathrm{~s}), 137.0(\mathrm{~s}), 139.6 \mathrm{ppm}$ 550 (s). - HRMS: $\mathrm{C}_{26} \mathrm{H}_{26} \mathrm{~S}_{2}$ : calcd.: 402.147 ; found: 402.147.

551 Dithiacyclophane 20: According to the above general procedure 552 was coupled 10b (0.60 g, $2 \mathrm{mmol})$ with m-xylylene dibromide (m553 11, $0.53 \mathrm{~g}, 2 \mathrm{mmol})$. The crude product was purified by silica 554 gel column chromatography with dichloromethane/hexane (2:3, $555 \mathrm{~V} / \mathrm{v})$ to provide 20 as a colorless powder $(0.64 \mathrm{~g}, 80 \%)$, m. p. $556224{ }^{\circ} \mathrm{C} . \quad-{ }^{1} \mathrm{H} \quad \mathrm{NMR}: \delta=2.52-2.62\left(\mathrm{AA}^{\prime} \mathrm{BB}^{\prime}, 4 \mathrm{H}\right), \quad 2.84-3.04$ $557\left(\mathrm{CC}^{\prime} \mathrm{DD}^{\prime}, 4 \mathrm{H}\right), 3.36(\mathrm{~d}, J=12.3 \mathrm{~Hz}, 2 \mathrm{H}), 3.738,3.774$ (AB 
558 system, $J=13.3 \mathrm{~Hz}, 4 \mathrm{H}), 3.86(\mathrm{~d}, J=12.3 \mathrm{~Hz}, 2 \mathrm{H}), 6.26$ 559 (br. s, $2 \mathrm{H}), 6.36(\mathrm{~d}, J=7.7 \mathrm{~Hz}, 2 \mathrm{H}), 6.41(\mathrm{dd}, J=7.7$, $5601.8 \mathrm{~Hz}, 2 \mathrm{H}), 7.11$ ( $t, J=1.8 \mathrm{~Hz}, 1 \mathrm{H}), 7.45(2 \mathrm{H}), 7.55 \mathrm{ppm}$ 561 (1 H) (br. $\left.\mathrm{A}_{2} \mathrm{~B}, J=7.5 \mathrm{~Hz}\right) \cdot-{ }^{13} \mathrm{C} \mathrm{NMR}: \delta=31.5$ ( $\left.\mathrm{t}, 2 \mathrm{C}\right)$, $56234.6(t, 2 \mathrm{c}), 34.9(t, 2 \mathrm{c}), 37.3(t, 2 \mathrm{c}), 128.4(\mathrm{~d}, 2 \mathrm{c})$, $563130.5(d, 1 c), 132.54(d, 2 c), 132.60(d, 1 c), 132.72(d, 2$ $564 \mathrm{c}), 135.2(\mathrm{~d}, 2 \mathrm{c}), 135.4(\mathrm{~s}, 2 \mathrm{c}), 137.3(\mathrm{~s}, 2 \mathrm{c}), 138.6$ (, $5652 \mathrm{C}), 139.1 \mathrm{ppm}(\mathrm{s}, 2 \mathrm{C}) . \quad-\mathrm{HRMS}: \mathrm{C}_{26} \mathrm{H}_{26} \mathrm{~S}_{2}:$ calcd.: 402.147; 566 found: 402.147.

567 Dithiacyclophane 21: According to the above general procedure 568 was coupled 10b (0.60 g, 2 mmol) with p-xylylene dibromide ( $p-$ 569 11a, $0.53 \mathrm{~g}, 2 \mathrm{mmol})$. The crude product was purified by silica 570 gel column chromatography with dichloromethane/hexane (2:3, $571 \mathrm{~V} / \mathrm{v})$ to provide 21 as a colorless powder $(0.25 \mathrm{~g}, 32 \%)$, m. p. $572221{ }^{\circ} \mathrm{C}$ (decomp.). $-{ }^{1} \mathrm{H}$ NMR: $\delta=2.61(\mathrm{~d}, J=11.7 \mathrm{~Hz}, 2 \mathrm{H})$, $5732.81-2.99(\mathrm{~m}, 6 \mathrm{H}), 2.84(\mathrm{~d}, J=11.7 \mathrm{~Hz}, 2 \mathrm{H}), 3.23-3.35$ (m, $5742 \mathrm{H}), 3.89,3.95$ (AB system, $J=12.1 \mathrm{~Hz}, 4 \mathrm{H}), 6.18$ (br s, 2 $575 \mathrm{H}), 6.39(\mathrm{dd}, J=7.7,1.8 \mathrm{~Hz}, 2 \mathrm{H}), 6.45(\mathrm{~d}, J=7.7 \mathrm{~Hz}, 2 \mathrm{H})$, $5767.23,7.76 \mathrm{ppm}\left(\mathrm{AA}^{\prime} \mathrm{XX} \mathrm{X}^{\prime}, N=2.3 \mathrm{~Hz}, 4 \mathrm{H}\right) .{ }^{13} \mathrm{C} \mathrm{NMR}: \delta=32.5$ $577(t), 34.2(t), 34.8(t), 36.6$ (t), 130.3 (d), 130.4 (d), 132.6 $578(d), 132.9(d), 135.0$ (s), $135.4(d), 136.9$ (s), 138.8 (s), 579 139.0 (s) ppm. - HRMS: $\mathrm{C}_{26} \mathrm{H}_{26} \mathrm{~S}_{2}$ : calcd.: 402.147; found: $580 \quad 402.147$.

581 Coupling of $10 \mathrm{~b}(0.30 \mathrm{~g}, 1.0 \mathrm{mmol})$ and $10 \mathrm{a}(0.40 \mathrm{~g}, 1.0 \mathrm{mmol})$ : 582 under the above conditions after chromatography with 583 dichloromethan/hexane (3:7) the thiacyclophane 14 was obtained 
$584(0.219,80 \%$, with respect to the thiol 10b): spectroscopic 585 data as above.

586 Repeating the experiment (same concentrations of coupling 587 partners $\mathbf{1 0 a}$ and $\mathbf{1 0 b}$ ) in the presence of cesium hydroxide $588(0.38 \mathrm{~g}, 2.5 \mathrm{mmol})$ yielded after work-up (column 589 chromatography with dichloromethane/hexane $=2: 1(\mathrm{v} / \mathrm{v})$ the 590 thiacyclophane $14(0.16 \mathrm{~g}, 60 \%)$ and the dimer 22 (26.0 $\mathrm{mg}$, 5\%) 591 as colorless powder, m.p. $195{ }^{\circ} \mathrm{C} .-{ }^{1} \mathrm{H}$ NMR: $\delta=2.89-3.10(\mathrm{~m}$, $59212 \mathrm{H}), 3.50-3.53(\mathrm{~m}, 4 \mathrm{H}), 4.37(\mathrm{~d}, J=12.7 \mathrm{~Hz}, 4 \mathrm{H}), 4.94$ $593(\mathrm{~d}, J=12.7 \mathrm{~Hz}, 4 \mathrm{H}), 6.26(\mathrm{dd}, J=7.8,1.7 \mathrm{~Hz}, 4 \mathrm{H}), 6.35$ $594(\mathrm{~d}, J=7.8 \mathrm{~Hz}, 4 \mathrm{H}), 6.45 \mathrm{ppm}(\mathrm{d}, J=1.7 \mathrm{~Hz}, 4 \mathrm{H}) .{ }^{13} \mathrm{C}$ NMR: $595 \delta=137.6,136.0,134.6,134.4,134.3,132.7,37.4,35.0,34.6$ 596 ppm. - MS (EI, $70 \mathrm{eV}): \mathrm{m} / \mathrm{z}\left(\frac{\circ}{0}\right)=532\left(6, \mathrm{M}^{+}\right), 266(20), 147$ $597(50), 104(100) .-\mathrm{C}_{36} \mathrm{H}_{36} \mathrm{~S}_{2}$ (532.80): calcd.: C 81.16, H 6.81, S 598 12.03; found: C 81.19, H 6.80, S 12.06.

599 Disulfone 23 from disulfide 20: To a solution of the 600 cyclophane $20(1.2 \mathrm{~g}, 3.0 \mathrm{mmol})$ in a $1: 1$-mixture of 601 dichloromethane/glacial acetic acid $(300 \mathrm{~mL})$ was added at $0{ }^{\circ} \mathrm{C}$ 602 under stirring a solution of m-chloroperbenzoic acid (MCPBA, $60370 \%$ purity, $3.52 \mathrm{~g}, 14.3 \mathrm{mmol}$ ) in glacial acetic acid (100 $604 \mathrm{~mL})$. The reaction mixture was slowly warmed to room temp., and 605 stirred for $3 \mathrm{~d}$. The precipitated disulfone was removed by 606 filtration, washed with trichloromethane, and dried: $1.26 \mathrm{~g}$ 607 (90\%) of colorless crystals, m. p. $282{ }^{\circ} \mathrm{C} . \quad-$ IR (KBr): $608 \mathrm{nu}($ tilde $)=1320$ and $1115 \mathrm{~cm}^{-1}\left(\mathrm{vs}, \mathrm{SO}_{2}\right) \cdot-{ }^{1} \mathrm{H}$ NMR $\left(\mathrm{DMSO}-\mathrm{d}_{6}\right): \delta$ $609=2.50-2.52(\mathrm{~m}, 4 \mathrm{H}), 2.96(\mathrm{~m}, 4 \mathrm{H}), 3.96-4.18(\mathrm{~m}, 4 \mathrm{H}), 4.64$ 
$610(\mathrm{~m}, 4 \mathrm{H}), 6.33(\mathrm{br} . \mathrm{s}, 2 \mathrm{H}), 6.50(\mathrm{~d}, \mathrm{~J}=7.7 \mathrm{~Hz}, 2 \mathrm{H}), 6.57$ $611(\mathrm{dd}, J=7.7,1.3 \mathrm{~Hz}, 2 \mathrm{H}), 7.62-7.67(\mathrm{~m}, 3 \mathrm{H}), 7.98 \mathrm{ppm}$ (br. $612 \mathrm{~s}, 1 \mathrm{H}) . \quad-{ }^{13} \mathrm{C}$ NMR: $\delta=139.8,139.3,135.1,133.8,131.9$, $613131.0,129.9,124.7,61.1,54.0,34.2,31.0$ ppm. - MS (EI, 70 $614 \mathrm{eV}): m / z\left(\frac{\circ}{\circ}\right)=466\left(44, \mathrm{M}^{+}\right), 402(8), 338(60), 337(100), 219$ 615 (76), $104(44) .-\mathrm{C}_{26} \mathrm{H}_{26} \mathrm{O}_{4} \mathrm{~S}_{2}$ (466.61): calcd.: C 66.93, H 5.62, 616 S 13.74; found: C 66.91, H 5.63, S 1372.

617 Diene 24: To a suspension of the disulfone $23(0.47 \mathrm{~g}, 1.0$ $618 \mathrm{mmol})$ in dichloromethane/trichloromethane (50 $\mathrm{mL}, 2: 1, \mathrm{v} / \mathrm{v})$ 619 was added carbon tetrachloride $(0.5 \mathrm{~mL})$, aqueous sodium 620 hydroxide solution (25 mL, 10\%), and cetyltrimethylammonium 621 chloride $(0.18 \mathrm{~g}, 0.50 \mathrm{mmol})$. The mixture was heated at reflux 622 with vigorous stirring for 3 d. After cooling to room temp., 623 the organic phase was separated, dried, and the solvent was 624 removed in vacuo. Column chromatography (silica gel; 625 hexane/dichloromethane $=8: 2)$ yielded $24(30.0 \mathrm{mg}$, 9\%) as 626 colorless crystals, m. p. $120{ }^{\circ} \mathrm{C}$ (decomp.) - ${ }^{1} \mathrm{H}$ NMR $\left(\mathrm{CD}_{2} \mathrm{Cl}_{2}\right.$; 627 protons are labeled as in formula 24): $\delta=2.42-2.61$ (m, 2 H), $6282.91-3.01(\mathrm{~m}, 2 \mathrm{H}), 3.09-3.35(\mathrm{~m}, 4 \mathrm{H}), 5.79\left(\mathrm{br} . \mathrm{s}, 1 \mathrm{H} ; \mathrm{H}^{\mathrm{m}}\right)$, $6295.90), 6.14\left(\mathrm{~d}, J=11.0 \mathrm{~Hz}, 1 \mathrm{H} ; \mathrm{H}^{\mathrm{k}}\right), 6.66(\mathrm{~d}, J=11.0 \mathrm{~Hz}, 1$ $\left.630 \mathrm{H} ; \mathrm{H}^{j}\right), 6.72\left(\mathrm{dd}, J=7.3,1.4 \mathrm{~Hz}, 1 \mathrm{H} ; \mathrm{H}^{\mathrm{i}}\right), 6.77(\mathrm{~d}, J=7.3$ $\left.631 \mathrm{~Hz}, 1 \mathrm{H} ; \mathrm{H}^{\mathrm{h}}\right), 6.80$ (br. $\left.\mathrm{d}, J=7.3 \mathrm{~Hz}, 1 \mathrm{H} ; \mathrm{H}^{9}\right), 6.85$ ( dd, $J=$ $6327.3,1.6,1 \mathrm{H} ; \mathrm{H}^{\mathrm{f}}$ ), 6.94 (br. s, $\left.1 \mathrm{H} ; \mathrm{H}^{\mathrm{e}}\right), 7.10$ (br. $\mathrm{d}, \mathrm{J}=7.7$ $633 \mathrm{~Hz}, 1 \mathrm{H} ; \mathrm{H}^{\mathrm{d}}$ ), 7.17 (br. $\left.\mathrm{d}, J=7.7 \mathrm{~Hz}, 1 \mathrm{H} ; \mathrm{H}^{\mathrm{c}}\right) 7.32$ ( $\mathrm{t}, J=$ $6347.7 \mathrm{~Hz}, 1 \mathrm{H}$; $\left.\mathrm{H}^{\mathrm{b}}\right), 7.51 \mathrm{ppm}\left(\mathrm{td}, J=1.8,0.6 \mathrm{~Hz}, 1 \mathrm{H}\right.$; $\left.\mathrm{H}^{\mathrm{a}}\right) .-{ }^{13} \mathrm{C}$ $635 \operatorname{NMR}\left(\mathrm{CD}_{2} \mathrm{Cl}_{2}\right): \delta=34.7$ (t), 34.95 (t), 35.04 (t), 35.08 (t), 


\begin{abstract}
$636125.7(d), 126.5(d), 129.0(d), 129.3(d), 130.0(d), 130.3$
$637(d), 130.6(d), 131.2(d), 132.3(d), 133.9(d), 135.2(d)$,

$638135.5(\mathrm{~s}), 136.0(\mathrm{~s}), 136.2(\mathrm{~d}), 136.9(\mathrm{~s}), 138.11(\mathrm{~s}), 138.16$

$639(\mathrm{~s}), 138.4(\mathrm{~d}), 138.9(\mathrm{~s}), 139.0(\mathrm{~s}, 2 \mathrm{C}), 139.3$ (s) ppm. - MS

$640(\mathrm{EI}, 70 \mathrm{eV}): \mathrm{m} / \mathrm{z}\left(\frac{\circ}{0}\right)=370\left(20, \mathrm{M}^{+}\right), 368\left(56, \mathrm{M}^{+}\right), 333(100)$,

641205 (45). - HRMS: calcd. 368.133, found 368.133. $-\mathrm{C}_{26} \mathrm{H}_{21} \mathrm{Cl}$

642 (368.90): calcd.: C 84.65, H 5.74, Cl 9.61; found: 84.69, H

$643 \quad 5.74$.
\end{abstract}

644 Flash vacuum pyrolysis of 23: In a flash vacuum pyrolysis

645 apparatus disulfone $23(0.47 \mathrm{~g}, 1.0 \mathrm{mmol})$ was pyrolyzed at $646500-540{ }^{\circ} \mathrm{C}$ and 0.2 torr. The pyrolysate was frozen out on a 647 cold finger and the product mixture dissolved in 648 dichloromethane. Chromatography (silica gel; dichloro649 methane/hexane = 1:9) yielded ca. $80 \mathrm{mg}$ (22\%) of 26. - NMR: 650 Mixture displaying methyl signals at $\delta_{H}=2.13$ and 2.25 ppm and 651 at $\delta_{C}=18.9$ and $21.0 \mathrm{ppm}$. $-\mathrm{MS}(\mathrm{EI}, 70 \mathrm{eV}): \mathrm{m} / \mathrm{z}\left(\frac{\circ}{0}\right)=340$ $652\left(100, \mathrm{M}^{+}\right), 249(8), 235(22), 221(56), 119(50) \cdot-\mathrm{C}_{26} \mathrm{H}_{28}$ 653 (340.50): calcd.: C 91.71, H 8.29; found 91.74 H 8.30.

654

655 X-Ray structure determinations

656 Crystals were mounted in inert oil on glass fibres and 657 transferred to the cold gas stream of the diffractometer 658 (Siemens P4 for 21, otherwise stoe STADI-4). Intensity data 659 were recorded using monochromated Mo $K \alpha$ radiation $(\lambda=$ $6600.71073 \AA$ ) . Absorption corrections were not performed. The 661 structures were refined anisotropically on $F^{2}$ using the 
662 program SHELXL-97 [20]. Hydrogens were included using a 663 riding model starting from calculated positions. Special 664 features: Compound 14 crystallizes in the non-centrosymmetric 665 space group Pna2 ${ }_{1}$. The structure was refined as an 666 enantiomeric twin, with a volume ratio of $0.58 / 0.42(10)$ for 667 the two components. Compound 21 crystallizes as a cyclohexane 668 1/4-solvate; the solvent molecule adopts two alternative 669 positions around an inversion centre. Dimensions of 670 disordered groups should be interpreted with caution. The 671 crystallographic data of 14, 19, 20 and 21 are collected in 672 Table. 1

673

674 Table 1 here please

675

676

677 Table 1. Crystallographic data.

678

Compound

Formula

$M_{\text {r }}$

Habit

Crystal size (mm)

Crystal system

Space group

Temperature $\left({ }^{\circ} \mathrm{C}\right)$

Cell constants:
14

$$
\mathrm{C}_{18} \mathrm{H}_{18} \mathrm{~S}
$$

266.38 colourless block

$0.7 \times 0.6 \times 0.4$ orthorhombic

$P_{n a 2}$

$-130$

17.285(5)
19

$\mathrm{C}_{26} \mathrm{H}_{26} \mathrm{~S}_{2}$

402.59

colourless block

$0.4 \times 0.4 \times 0.3$

monoclinic

$P 2{ }_{1} / c$

$-130$

$8.790(2)$
20

$\mathrm{C}_{26} \mathrm{H}_{26} \mathrm{~S}_{2}$

402.59

colourless tablet

$0.4 \times 0.4 \times 0.2$

monoclinic

$P 2_{1} / c$

$-130$

17.927(4)
$21 \cdot 1 / 4 \mathrm{C}_{6} \mathrm{H}_{12}$

$\mathrm{C}_{27.5} \mathrm{H}_{29} \mathrm{~S}_{2}$ 423.63 colourless needle $1.0 \times 0.2 \times 0.1$ monoclinic $P 2{ }_{1} / c$ $-100$ $8.663(2)$ 


\begin{tabular}{|c|c|c|c|c|}
\hline$b(\AA)$ & $8.230(2)$ & $13.179(3)$ & $7.831(2)$ & $32.081(6)$ \\
\hline$c(\AA)$ & $9.159(2)$ & $17.554(4)$ & $15.020(3)$ & $15.827(3)$ \\
\hline$\alpha\left(^{\circ}\right)$ & 90 & 90 & 90 & 90 \\
\hline$\beta\left(^{\circ}\right)$ & 90 & $90.93(2)$ & $106.10(3)$ & $90.17(2)$ \\
\hline$\gamma\left(\left(^{\circ}\right)\right.$ & 90 & 90 & 90 & 90 \\
\hline$V\left(\AA^{3}\right)$ & 1302.9 & 2033.2 & 2025.8 & 4398.7 \\
\hline$Z$ & 4 & 4 & 4 & 8 \\
\hline$D_{\mathrm{x}}\left(\mathrm{Mg} \mathrm{m}^{-3}\right)$ & 1.358 & 1.315 & 1.320 & 1.279 \\
\hline$\mu\left(\mathrm{mm}^{-1}\right)$ & 0.23 & 0.27 & 0.27 & 0.25 \\
\hline$F(000)$ & 568 & 856 & 856 & 1808 \\
\hline $2 \theta_{\max }$ & 50 & 50 & 50 & 50 \\
\hline Refl. measured & 2305 & 3715 & 3857 & 9761 \\
\hline Refl. indep. & 2305 & 3588 & 3574 & 7724 \\
\hline$R_{\text {int }}$ & - & 0.033 & 0.023 & 0.035 \\
\hline Parameters & 173 & 253 & 253 & 560 \\
\hline Restraints & 1 & 0 & 0 & 9 \\
\hline$w R\left(F^{2}\right.$, all refl. $)$ & 0.094 & 0.128 & 0.111 & 0.109 \\
\hline$R(F,>4 \sigma(F))$ & 0.035 & 0.052 & 0.051 & 0.050 \\
\hline$S$ & 1.06 & 1.03 & 1.03 & 0.85 \\
\hline $\max . \Delta \rho\left(\mathrm{e} \AA^{-3}\right)$ & 0.16 & 0.24 & 0.31 & 0.26 \\
\hline
\end{tabular}

679

680

681

682 Table 1: Crystallographic data of 14, 19, 20, and 21.

683

684

685 Crystallographic data have been deposited with the Cambridge 686 Crystallographic Data Centre as supplementary publications no. $687 \quad \mathrm{CCDC}-1063540 \quad(14), \quad-1063541 \quad(19), \quad-1063537 \quad(20), \quad-1063536$ 
688 (21). Copies of the data can be obtained free of charge from 689 www.ccdc.cam.ac.uk/data_request/cif.

690

691 